Article

\title{
A Systematic Investigation into the Environmental Fate of Microcystins and The Potential Risk: Study in Lake Taihu
}

\author{
Junmei Jia ${ }^{1,3,4,5}$, Qiuwen Chen ${ }^{2, *}$ and Torben L. Lauridsen ${ }^{4,5}$ \\ 1 Research Center for Eco-Environmental Sciences, Chinese Academy of Sciences, Beijing 100085, China; \\ jiadao_mei@126.com \\ 2 Center for Eco-Environmental Research, Nanjing Hydraulic Research Institute, Nanjing 210029, China \\ 3 Department of Environmental Sciences, University of the Chinese Academy of Sciences, \\ Beijing 100049, China \\ 4 Department of Bioscience, Aarhus University, Vejlsøvej 25, 8600 Silkeborg, Denmark; tll@bios.au.dk \\ 5 Sino-Danish Center for Education and Research (SDC), Beijing 100190, China \\ * Correspondence: qwchen@nhri.cn; Tel./Fax: +86-258-582-9765
}

Academic Editor: Miquel Lürling

Received: 23 March 2016; Accepted: 24 May 2016; Published: 2 June 2016

\begin{abstract}
A systematic investigation was conducted in Lake Taihu in autumn of 2013 and 2014, in order to understand the environmental fate of microcystins (MCs) and evaluate the health risk from MCs. Samples of water, algal cells, macrophytes, shrimps and fish were taken to detect MCs by HPLC-MS/MS after solid phase extraction. Widespread MC contamination in water, algal cells, macrophytes, shrimps and fish was found in Lake Taihu. The ubiquitous presence of MCs in water, algal cells and biota was found in $100 \%$ of samples. MC accumulation was in the order of primary producer $>$ tertiary consumer $>$ secondary consumer $>$ primary consumer. The highest levels of MCs in macrophytes, shrimps and fish tissue were found in Potamogeton maackianus, Exopalaemon modestus, and Hyporhamphus intermedius, respectively. The MCs level in shrimps and the tissues of three fish species, Neosalanx tangkahkeii taihuensis, Coilia ectenes and silver carp, was closely linked to their dietary exposure. Ceratophyllum demersum L. was an ideal plant for introduction into lakes to protect against Microcystis blooms and MCs, due to its ability to absorb nutrients, accumulate large amounts of MCs and tolerate these toxins compared to other macrophytes. The average daily intakes (ADIs) of MCs for Exopalaemon modestus and three fish species, Coilia ectenes, Hyporhamphus intermedius and Carassius carassius, were all above the tolerable daily intakes (TDI) set by the World Health Organization (WHO), implying there existed potential threats to human health.
\end{abstract}

Keywords: microcystins; bioaccumulation; environment fate; health risk; Lake Taihu

\section{Introduction}

Cyanobacteria, widely known as blue-green algae, are prokaryotes and are some of the earliest known organisms [1]. The presence of cyanobacteria dates back 3.5 billion years [1]. Cyanobacteria have a diverse group and are widely distributed throughout the world's lakes and reservoirs [2]. Cyanobacterial blooms remain a growing worldwide concern [3-5]. The increase in cyanobacteria Microcystis producing hepatotoxic microcystins (MCs) has been highly worrisome [5]. Several genera of cyanobacteria including Microcystis, Anabaena, Oscillatoria, Nostoc and Anabaenopsis could produce MCs comprising a group of cyclic peptides [6]. Approximately 90 variants of MCs have been identified up to now [7].

MCs can have detrimental effects on phytoplankton, macrophytes, aquatic animals and even human beings. MCs inhibit the growth of aquatic organisms (including phytoplankton, macrophytes, 
invertebrates and vertebrates) [8,9], reduce fecundity [9] and accumulate into organisms, including mussels and fish. MCs have caused mass death of wild animals, livestock and aquatic life in many places in the world [10-16].

MCs have acutely toxic effects on humans such as jaundice, shock, and abdominal pain, and can cause death in human beings $[1,17,18]$. Chronic exposure to microcystins may cause different health effects, such as liver damage [19], promotion of liver tumour progression [20] and liver cancer [3,21,22]. MCs have been detected in the blood sera of Chinese fishermen with obvious liver damage, because of exposure to MCs via drinking water and aquatic products [23].

A series of field studies on MC contamination in water and aquatic animals were conducted in Lake Taihu around 2007 when a notorious heavy cyanobacterial bloom occurred [24-26]. During the algal bloom crisis in Lake Taihu in 2007, about 2 million people could not access tap water and had to rely on bottled water for 1 week $[27,28]$. In the years around 2007, Lake Taihu suffered from heavy blooms every summer. Extensive studies have been conducted on accumulation of MCs in fish, shrimps and snails [28-33], but systematic investigation of MCs in the food web including algal cells, macrophytes, shrimps and fish is scarce. Most of the studies were conducted during heavy cyanobacterial blooms, and all the results indicated that MC accumulation could pose high risks to higher trophic levels and human beings. But is it absolutely safe when there is no obvious bloom? A study in the James River Estuary indicated that potential health risks may exist in non-bloom periods [34]. Another study in the San Francisco Estuary indicated that Microcystis, even at low abundance, may have influences on fishery production via toxic and food web at multiple trophic levels [35]. Although there have not been large cyanobacterial blooms occurred in Lake Taihu since 2008, chlorophyll a concentration and average density of cyanobacteria in Lake Taihu have been increasing in recent years [36]. Thus, a systematic investigation the fate of MCs in a typical Chinese lake ecosystem is needed.

In the present study, six species of macrophytes, two species of shrimps and seven species of fish were investigated. The studied species are either dominant species or common species in Lake Taihu. The objective of this study was to: (1) explore the environmental fate of MCs in the food web associated with water, algal cells, macrophytes, shrimps and fish species during autumn in 2013 and 2014; (2) evaluate the risks that MCs pose to aquatic organisms and human beings.

\section{Results}

\subsection{Spatial Differences of MCs in Water and Algal Cells of Lake Taihu}

The average MC concentration in the water of Lake Taihu in autumn of 2013 was $130.4 \pm 42.6 \mathrm{ng} / \mathrm{L}$, and it was $140.2 \pm 83.3 \mathrm{ng} / \mathrm{L}$ in autumn of 2014. The water in SC had the highest MC concentration of $202.0 \pm 71.4 \mathrm{ng} / \mathrm{L}$ in autumn of 2013, while there was not much difference in MC levels in the water in the other three areas of Lake Taihu (Table 1). Water in MLB and SC had higher MC concentrations than in the other two areas in autumn of 2014 (Table 1). The ratios of MC-LR/MCs and MC-RR/MCs in water were similar in WC, LC and MLB in 2013, but the ratios of MC-LR/MCs in the water of SC was much higher than in water from WC, LC and MLB. The ratios of MC-LR/MCs and MC-RR/MCs in water were similar in WC, SC, LC and MLB in 2014.

The average MC concentrations in algal cells and total MCs were both higher in autumn of 2014 than in autumn of $2013(p<0.05)$. The average MC concentrations in algal cells in autumn of 2013 and 2014 were $629.3 \pm 999.3 \mathrm{ng} / \mathrm{L}$ and $4104.5 \pm 8086.7 \mathrm{ng} / \mathrm{L}$, respectively. WC had higher MC level of $2491.0 \pm 1486.1 \mathrm{ng} / \mathrm{L}$ in algal cells than SC and LC in $2013(p<0.05)$, and MLB had higher MC in cells, $18,063.3 \pm 14,974.3 \mathrm{ng} / \mathrm{L}$ than SC and LC in $2014(p<0.05)$ (Table 1). The MC-RR/MCs ratio in algal cells was higher than the MC-LR/MCs and MC-YR/MCs ratios in algal cells of the four areas in 2013 and 2014, except for the MC-LR/MCs ratios in algal cells in LC and MLB in 2013. 
Table 1. MC concentrations in water and algal cells in different areas of Lake Taihu $(p<0.05)$.

\begin{tabular}{|c|c|c|c|c|c|c|c|c|c|c|}
\hline Year & Areas & $\begin{array}{c}\text { MC-RR } \\
\text { (ng/L) }\end{array}$ & $\begin{array}{c}\text { MC-LR } \\
\text { (ng/L) }\end{array}$ & $\begin{array}{c}\text { MC-YR } \\
\text { (ng/L) }\end{array}$ & MCs (ng/L) & $\begin{array}{l}\text { MC-RR Cell } \\
\text { (ng/L) }\end{array}$ & $\begin{array}{l}\text { MC-LR Cell } \\
\text { (ng/L) }\end{array}$ & $\begin{array}{l}\text { MC-YR Cell } \\
\text { (ng/L) }\end{array}$ & MCs Cell (ng/L) & Total MCs (ng/L) \\
\hline 2013 & WC & $46.9 \pm 17.2$ & $44.9 \pm 17.7$ & $36.9 \pm 10.9$ & $128.8 \pm 24.0$ & $1796.2 \pm 2300.6$ & $248.4 \pm 266.5$ & $446.4 \pm 548.0$ & $2491.0 \pm 1486.1^{b}$ & $2619.8 \pm 1510.1^{b}$ \\
\hline 2013 & $\mathrm{SC}$ & $37.5 \pm 0.31$ & $113.9 \pm 66.9$ & $50.6 \pm 4.8$ & $202.0 \pm 71.4$ & $87.0 \pm 62.2$ & $20.9 \pm 0.1$ & $39.0 \pm 23.8$ & $146.9 \pm 38.6^{\mathrm{a}}$ & $348.9 \pm 110.0 \mathrm{ab}$ \\
\hline 2013 & LC & $35.5 \pm 0.8$ & $47.0 \pm 17.0$ & $33.3 \pm 5.6$ & $115.8 \pm 16.2$ & $60.5 \pm 46.0$ & $115.2 \pm 111.3$ & $27.8 \pm 3.9$ & $203.6 \pm 113.2^{a}$ & $319.3 \pm 108.3^{a}$ \\
\hline 2013 & MLB & $36.3 \pm 5.1$ & $38.2 \pm 2.7$ & $30.0 \pm 0.5$ & $104.5 \pm 7.3$ & $137.6 \pm 148.7$ & $345.4 \pm 334.8$ & $44.1 \pm 30.6$ & $527.2 \pm 452.9^{a b}$ & $631.7 \pm 445.6^{\mathrm{ab}}$ \\
\hline 2014 & WC & $35.1 \pm 2.5$ & $27.8 \pm 3.3$ & $14.4 \pm 0.5$ & $77.3 \pm 5.3$ & $626.1 \pm 365.9$ & $280.9 \pm 165.5$ & $43.7 \pm 18.7$ & $950.8 \pm 550.1 \mathrm{AB}$ & $1028.1 \pm 555.4^{\mathrm{A}}$ \\
\hline 2014 & SC & $90.7 \pm 15.4$ & $95.1 \pm 42.2$ & $20.7 \pm 0.7$ & $206.4 \pm 58.3$ & $487.5 \pm 481.7$ & $261.2 \pm 235.6$ & $35.0 \pm 24.8$ & $783.7 \pm 742.1^{\mathrm{A}}$ & $990.1 \pm 800.4^{\mathrm{A}}$ \\
\hline 2014 & LC & $53.8 \pm 24.1$ & $45.3 \pm 20.0$ & $13.9 \pm 7.0$ & $112.9 \pm 47.6$ & $1087.7 \pm 1552.1$ & $454.0 \pm 620.4$ & $68.2 \pm 76.5$ & $1609.8 \pm 2248.5^{\mathrm{A}}$ & $1722.8 \pm 2291.0^{\mathrm{A}}$ \\
\hline 2014 & MLB & $111.5 \pm 94.0$ & $86.5 \pm 66.0$ & $20.5 \pm 8.0$ & $218.5 \pm 168.0$ & $11,624.8 \pm 9689.1$ & $5679.4 \pm 4597.4$ & $759.1 \pm 687.7$ & $18,063.3 \pm 14,974.3^{\text {В }}$ & $18,281.9 \pm 15,142.3^{8}$ \\
\hline
\end{tabular}

$\mathrm{a}, \mathrm{ab}, \mathrm{b}$ are symbols whether there were significant differences in different areas of Lake Taihu in 2013; A, AB and B are symbols whether there were significant differences in different areas of Lake Taihu in 2014. The MCs in the area marked with "a" had significant differences with the area marked with " $b$ ", while it had no significant differences with the area marked with "ab". This applies to "A", "B" and "AB" as well. 


\subsection{Accumulation of MCs in Macrophytes of Four Areas of Lake Taihu}

There were differences in MC accumulation among different macrophytes. The MC concentration in Lemna minor in LC in 2013 was as high as $8200.8 \pm 282.1 \mathrm{ng} / \mathrm{g}$ dry weight (dw), while the MC content in Ceratophyllum inflatum Jao was $183.6 \pm 6.3 \mathrm{ng} / \mathrm{g} \mathrm{dw}$. There were also differences among the same macrophytes sampled from different locations of Lake Taihu in 2013. The MC concentration of Potamogeton maackianus in LC in 2013 was $44,727.1 \pm 1538.6 \mathrm{ng} / \mathrm{g} \mathrm{dw}$, while it was $68.4 \pm 2.4 \mathrm{ng} / \mathrm{g} \mathrm{dw}$ in SC of Lake Taihu. The MC concentration in Ceratophyllum inflatum Jao in WC was higher than in LC in 2013 (Figure 1A). The MC content in Ceratophyllum demersum L. in MLB was much higher than in WC (Figure 1B). In addition, the MC concentration in Potamogeton maackianus in LC of 2013 was much higher than in MLB and SC (Figure 1C). There were no great differences in MC contents in Potamogeton maackianus in MLB, LC and SC in 2014 (Figure 1D). Significant positive relationships were found between MCs in Ceratophyllum and MC-RR in algal cell $(p<0.05)$. Similar relation was also observed between MCs in Ceratophyllum and MCs in algal cell $(p<0.05)($ Table 2). No significant relationships were found between MCs in Potamogeton maackianus and MCs in algal cells. Negative relationship was found between MCs in Ceratophyllum and total MCs in water, while positive relationship was found between MCs in Potamogeton maackianus and total MCs in water (Table 2).
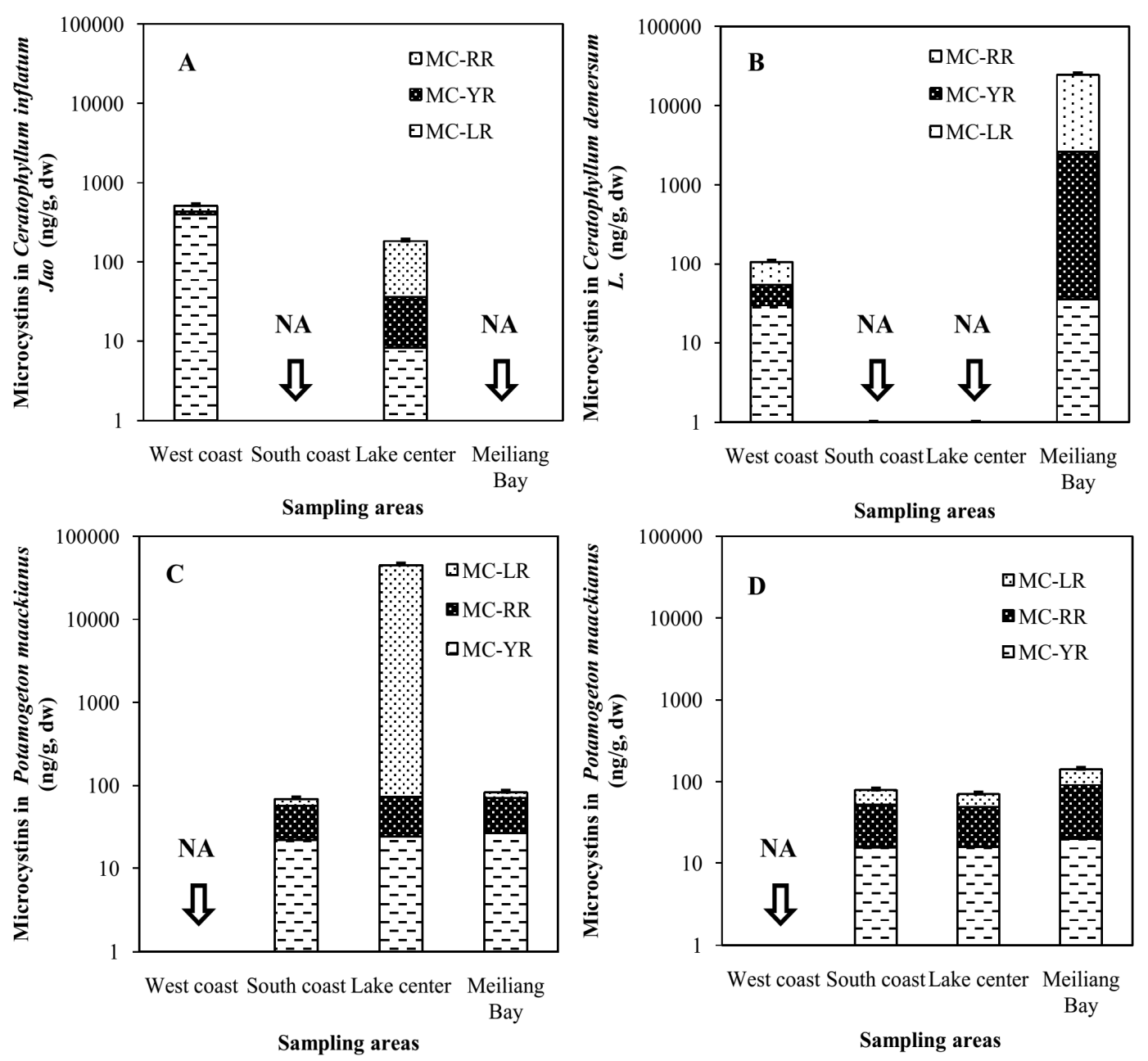

Figure 1. MC concentrations in three hydrophyte species from different areas of Lake Taihu in autumn of 2013 and 2014. (A) Ceratophyllum inflatum Jao in autumn of 2013; (B) Ceratophyllum demersum L. in autumn of 2013; (C) Potamogeton maackianus in autumn of 2013; (D) Potamogeton maackianus in autumn of 2014. NA, No data. 
Table 2. Pearson correlations between MC in macrophytes and MC in water and algal cells.

\begin{tabular}{ccccccccc}
\hline \multirow{2}{*}{ Correlations } & \multicolumn{4}{c}{ Ceratophyllum } & \multicolumn{4}{c}{ Potamogeton maackianus } \\
& MC-RR & MC-LR & MC-YR & MCs & MC-RR & MC-LR & MC-YR & MCs \\
\hline MC-RR (water) & 0.83 & 0.06 & -0.36 & -0.51 & 0.55 & -0.53 & -0.58 & -0.38 \\
MC-LR (water) & -0.19 & 0.36 & -0.92 & 0.64 & -0.02 & -0.24 & -0.33 & -0.37 \\
MC-YR (water) & 0.54 & 0.21 & -0.69 & -0.09 & -0.19 & -0.01 & 0.59 & 0.19 \\
MCs(water) & 0.1 & -0.35 & 0.92 & -0.57 & 0.27 & -0.46 & -0.4 & -0.4 \\
MC-RR (cells) & -0.93 & 0.21 & -0.33 & $\mathbf{0 . 9 6} *$ & -0.27 & 0.02 & 0.36 & -0.45 \\
MC-LR (cells) & 0.95 & -0.18 & 0.24 & -0.93 & -0.03 & 0.03 & 0.52 & 0.5 \\
MC-YR (cells) & $\mathbf{0 . 9 5 *}$ & -0.17 & 0.22 & -0.92 & -0.14 & 0.35 & 0.28 & 0.71 \\
MCs(cells) & -0.76 & 0.32 & -0.65 & $\mathbf{0 . 9 8} *$ & -0.29 & -0.07 & 0.44 & -0.54 \\
Total MC-RR & -0.36 & -0.27 & 0.8 & -0.12 & -0.56 & 0.51 & -0.07 & 0.21 \\
Total MC-LR & -0.64 & -0.16 & 0.6 & 0.24 & -0.68 & 0.49 & -0.38 & -0.12 \\
Total MC-YR & -0.89 & 0.003 & 0.22 & 0.65 & -0.07 & -0.31 & -0.11 & -0.55 \\
Total MCs & 0.95 & -0.09 & -0.01 & -0.8 & -0.08 & 0.39 & 0.04 & 0.75 \\
\hline
\end{tabular}

\subsection{Accumulation of MCs in Shrimp and Fish in MLB of Lake Taihu}

The mean MC concentration in shrimps of Lake Taihu in 2013 and 2014 was $84.7 \pm 31.8$ (mean $\pm \mathrm{SD}$ ) $\mathrm{ng} / \mathrm{g} \mathrm{dw}$ and $91.4 \pm 30.5 \mathrm{ng} / \mathrm{g} \mathrm{dw}$, respectively. Both Exopalaemon modestus and Macrobrachium nipponense had slightly higher MC concentrations in 2014 than in 2013 (Figure 2). Exopalaemon modestus had higher MCs than Macrobrachium nipponense in both 2013 and 2014.

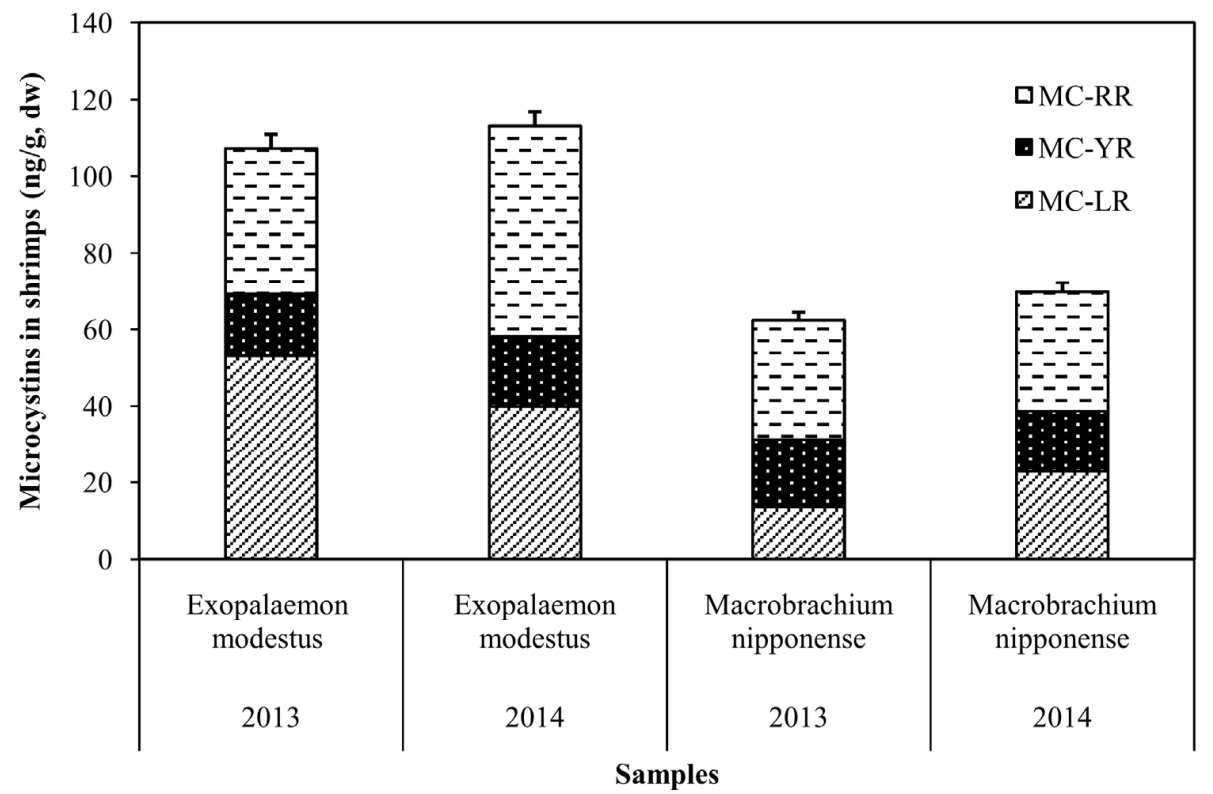

Figure 2. MC concentrations in two shrimp species sampled in MLB of Lake Taihu.

The average MC concentration in tissue of the same fish species in Lake Taihu sampled in 2013 and 2014 was $59.0 \pm 14.4 \mathrm{ng} / \mathrm{g} \mathrm{dw}$ and $90.9 \pm 20.2 \mathrm{ng} / \mathrm{g} \mathrm{dw}$, respectively. The Hyporhamphus intermedius had MC levels of $269.9 \pm 9.3 \mathrm{ng} / \mathrm{g}$ dw in its tissue, and Coilia ectenes had MC levels of $92.0 \pm 23.6 \mathrm{ng} / \mathrm{g}$ $\mathrm{dw}$ (Figure 3). The cyprinus carpio had MC levels of $59.0 \pm 2.0 \mathrm{ng} / \mathrm{g} \mathrm{dw}$ in tissue. There were three fish species, Neosalanx tangkahkeii taihuensis, Coilia ectenes and silver carp, caught both in 2013 and 2014. The MC contents of the three species were all higher in 2014 than in 2013, except for those in viscera of silver carp (Figure 4). 


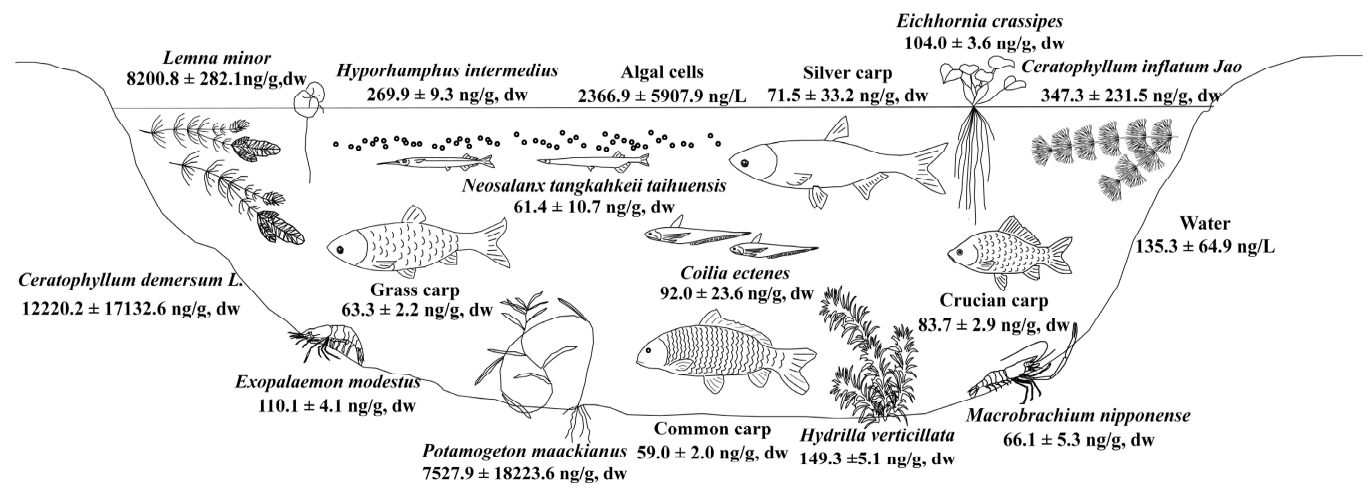

Figure 3. MC concentrations in the food web of Lake Taihu.
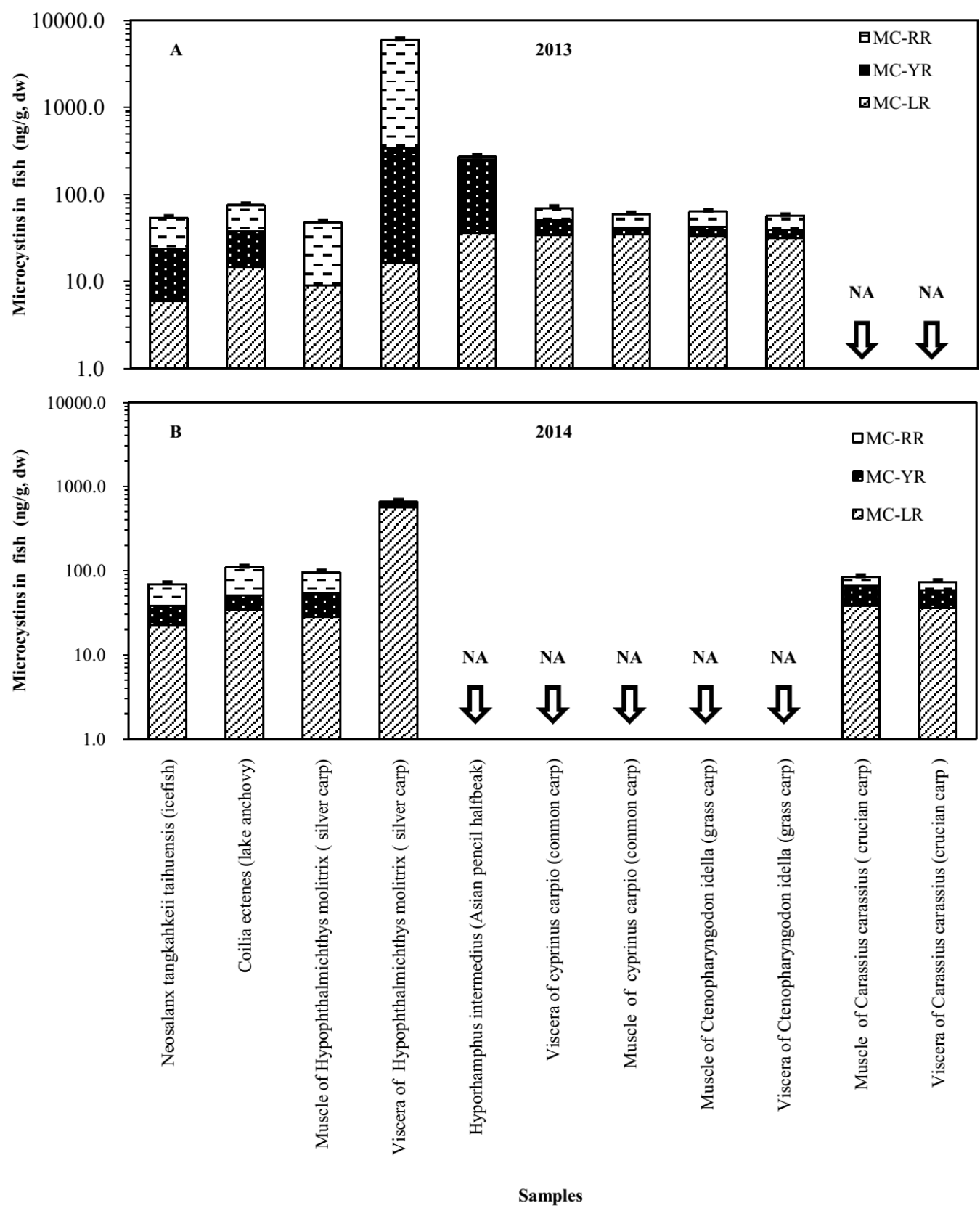

Figure 4. MC concentrations in fish sampled in MLB of Lake Taihu. NA, No data. 


\subsection{Fate of MCs in the Food Web of Lake Taihu}

The MC concentration in water of Lake Taihu ranged from $53.1 \mathrm{ng} / \mathrm{L}$ to $337.3 \mathrm{ng} / \mathrm{L}$ and $\mathrm{MC}$ in algal cells ranged from $118.2 \mathrm{ng} / \mathrm{L}$ to $28,651.7 \mathrm{ng} / \mathrm{L}$. Aquatic organisms in this study all had MCs presence in their bodies (Figure 3). The MC contents in macrophytes of Lake Taihu ranged from $68.4 \pm 2.4 \mathrm{ng} / \mathrm{g}$ dw to $44,727.1 \pm 1538.6 \mathrm{ng} / \mathrm{g} \mathrm{dw}$. The MC contents in shrimp ranged from $62.3 \pm 2.1 \mathrm{ng} / \mathrm{g} \mathrm{dw}$ to $113.0 \pm 3.9 \mathrm{ng} / \mathrm{g} \mathrm{dw}$, while MC in fish tissue ranged from $48.0 \pm 1.7 \mathrm{ng} / \mathrm{g}$ $\mathrm{dw}$ to $269.9 \pm 9.3 \mathrm{ng} / \mathrm{g} \mathrm{dw}$. Extremely high MC contents were found in macrophytes, such as Ceratophyllum demersum L., Lemna minor and Potamogeton maackianus (Figure 5). Relatively high MC contents were found in macrophytes, shrimps and fish, such as Ceratophyllum inflatum Jao, Exopalaemon modestus and Hyporhamphus intermedius (Figure 3). Relatively low MC contents were found in fish, such as common carp and grass carp (Figure 5). MC-RR was the main congener of MCs in algal cells, macrophytes, shrimps and fish. The MC-RR in algal cells, macrophytes, shrimps and fish of MLB accounted for $43 \% \pm 25 \%, 65 \% \pm 21 \%, 45 \% \pm 8 \%$ and $50 \% \pm 17 \%$ of MCs, respectively. The MC-LR in algal cells, macrophytes, shrimps and fish of MLB accounted for $46 \% \pm 18 \%, 17 \% \pm 18 \%, 35 \% \pm 11 \%$ and $28 \% \pm 20 \%$ of MCs, respectively. The MC-LR/MCs ratio of algal cells was significantly higher than the ratio of macrophytes in MLB $(p<0.05)$.

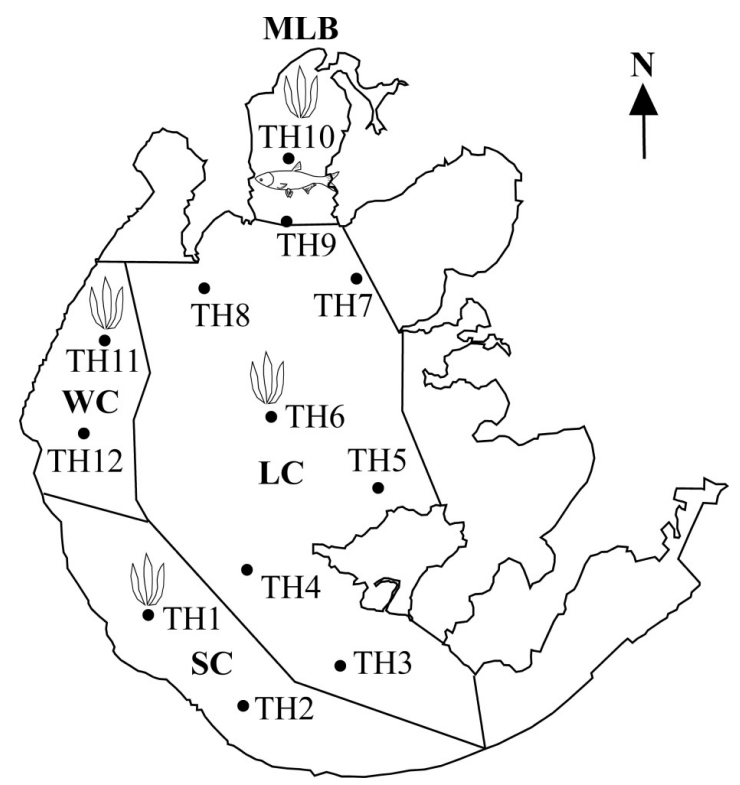

Figure 5. Sampling sites of water, hydrophytes and aquatic animals in Lake Taihu. TH, Taihu; MLB, Meiliang Bay; SC, South coast; WC, West coast; LC, lake centre.

\subsection{Risk of MCs to Local Residents}

The exposure routes of MCs to local residents around Lake Taihu are mainly drinking water and food. A guideline value of $1.0 \mu \mathrm{g} / \mathrm{L}$ for MC-LR was set up in drinking water by [37]. If only the $\mathrm{MC}$ in water was taken into consideration, the MC concentration was much lower than $1.0 \mu \mathrm{g} / \mathrm{L}$. However, the total MC in water, including the MC in cells, was much higher than $1.0 \mu \mathrm{g} / \mathrm{L}$ in WC, LC (2014) and MLB (2014). Dietary exposures of humans to MCs were calculated for 2 shrimp and 7 fish species (Table 3). The value of $0.04 \mu \mathrm{g} / \mathrm{kg}$ body mass per day derived from World Health Organization (WHO) [3] was used for tolerable daily intake (TDI) of MC-LR. According to medium lethal doses $\left(\mathrm{LD}_{50}\right)$ in mice [38], MC-YR and MC-RR correspond to 0.4 and $0.2 \mathrm{MC}$-LR equivalents, respectively. The dry weights were converted to wet weight by coefficients of 5 [23]. Assuming that an average body mass of an adult is $60 \mathrm{~kg}$ in China and the daily consumption of fish muscle is 300g [24], the average daily intakes (ADIs) of MCs from eating Exopalaemon modestus and Macrobrachium nipponense would be 0.0625 and $0.031 \mu \mathrm{g}$ MC-LR eq/kg body mass, respectively. The ADIs of Exopalaemon modestus and 
Macrobrachium nipponense are 1.6- and 0.8-fold the tolerable daily intake (TDI) proposed by the WHO. Exopalaemon modestus accumulated more MCs than Macrobrachium nipponense, but Exopalaemon modestus was more popularly served than Macrobrachium nipponense by local peoples. The mean daily intakes of MCs from eating Neosalanx tangkahkeii taihuensis, Coilia ectenes, Hyporhamphus intermedius, Hypophthalmichthys molitrix, Carassius carassius, Cyprinus carpio and Ctenopharyngodon idella would be $0.027,0.042,0.229,0.032,0.43,0.021$ and $0.025 \mu \mathrm{g}$ MC-LReq/kg body mass, respectively, corresponding to $0.7-, 1.1-, 5.7-, 0.8-, 1.1-, 0.5-$ and $0.6-$ times the TDI proposed by the WHO.

Table 3. Consumption risk assessment using tolerable daily intake (TDI).

\begin{tabular}{|c|c|c|c|c|}
\hline Species & $\begin{array}{c}\text { MC in } \\
\text { Edible Parts } \\
\text { (MC-LReq ng/g) }\end{array}$ & $\begin{array}{l}\text { Daily Intake for } \\
\text { a } 60 \mathrm{~kg} \text { Person } \\
\text { (MC-LR eq } \mu \mathrm{g} / \mathrm{kg} \\
\text { Body Weight) }\end{array}$ & $\begin{array}{c}\times \text { Lifetime TDI } \\
(0.04 \mu \mathrm{\mu g} / \mathrm{kg} \text { Body } \\
\text { Weight/day) }\end{array}$ & $\begin{array}{l}\text { Max Daily Intake } \\
\text { Not Exceeding the } \\
\text { Guideline (g) }\end{array}$ \\
\hline Exopalaemon modestus & 12.5 & 0.0625 & 1.6 & 192 \\
\hline Macrobrachium nipponense & 6.2 & 0.031 & 0.8 & 387 \\
\hline Neosalanx tangkahkeii taihuensis & 5.4 & 0.027 & 0.7 & 444 \\
\hline Hypophthalmichthys molitrix & 6.3 & 0.032 & 0.8 & 381 \\
\hline Carassius carassius & 8.6 & 0.043 & 1.1 & 279 \\
\hline Cyprinus carpio & 4.2 & 0.021 & 0.5 & 571 \\
\hline Ctenopharyngodon idella & 4.9 & 0.025 & 0.6 & 490 \\
\hline
\end{tabular}

\section{Discussion}

Widespread MC contamination was observed among water, algal cells, macrophytes (6 species), shrimp (2 species) and fish (7 species) in Lake Taihu in our study. The ubiquitous presence of MCs in water (100\% of samples), algal cells (100\% of samples) and aquatic organisms (100\% of samples) was surprising since there were no visible cyanobacterial blooms in most areas of Lake Taihu when we took those samples (The cyanobacteria abundance of Lake Taihu was $3.5 \times 10^{6}$ cells $/ \mathrm{L}$ and $7.5 \times 10^{7}$ cells $/ \mathrm{L}$ in autumn of 2013 and 2014, respectively). The average ratios of MC-LR/MCs in algal cells were higher than the ratios of shrimps, fish, and especially macrophytes $(p<0.05)$. These results indicated that organisms seem to be able to avoid toxic congeners or efficiently eliminate MCs in their bodies, given that MC-LR was the most toxic congener among MC-RR, MC-YR and MC-LR [38]. Extremely high MC contents were found in all macrophytes, which may result from a lack of efficient detox and elimination mechanisms in their tissue. The high concentration of MCs in macrophytes would pose a serious risk to the higher trophic level animals in the food web of Lake Taihu.

The MCs in phytoplankton may be eaten by primary consumers, such as filter fish, or secondary consumers via zooplankton [39]. The macrophytes would be directly eaten by herbivorous fish (grass carp) or ingested by other fish (crucian carp) and shrimp (Macrobrachium nipponense) as debris. There are some interesting results in the present study. The primary producers (phytoplankton and macrophyte) presented very high MC levels in their cells or tissues. The primary consumers (grass carp, silver carp, etc.) had lower MC concentrations in their tissues. Then the secondary consumers (Exopalaemon modestus, Macrobrachium nipponense, icefish) had higher MCs in their tissues than the primary consumers. The highest level consumers in this study (Asian pencil halfbeak, lake anchovy, etc.) had higher MC concentrations in tissue than the secondary consumers. This might be because the primary consumers, for example silver carp, ingest algal cells directly, and they may have evolutionary adaptations to possess high resistance to $\mathrm{MC}$ exposure and mechanisms to eliminate MCs in their body to counteract MCs [40]. The grass carp prefer to eat Hydrilla verticillata rather than Ceratophyllum demersum [41] and the former species accumulated much lower levels of MCs in this study. The higher level consumers, such as Hyporhamphus intermedius and Coilia ectenes, do not have a mechanism to counteract MCs, but they have an inevitable intake of MCs through predation, and thus they present high MC levels in the body. 
In the present study, considerable differences were found among macrophytes sampled from different areas of Lake Taihu, and all these differences arose from a distinct increase in the concentration of either MC-RR or MC-LR (Figure 1). There were great differences in MCs among different macrophyte species, which was also found by previous researchers [25,42]. The two floating macrophytes Ceratophyllum demersum L. and Lemna minor had the highest MC concentrations in their tissues. This is because they float on the surface of water together with algal cells or scum, and they can absorb the MCs rapidly as soon as MCs were released into water from algal cells $[43,44]$. This was further demonstrated by the significant positive relationship between MCs in Ceratophyllum and MCs in algal cells. Besides, these two plants have the ability to absorb large amounts of nutrients $[45,46]$ and the MCs may enter into the plant by a similar pathway as nutrients [47]. These two plants should have priority when macrophytes are introduced to lakes to protect against Microcystis blooms and MCs, because they play an vital role in elimination of MCs via accumulation in plant tissues, and Ceratophyllum demersum L. has higher tolerance to MCs compared to other macrophytes such as Hydrilla verticillata [48]. The negative relationship between MCs in Ceratophyllum and total MCs in water also indicated that the presence of Ceratophyllum demersum L. contributed to the lower total MCs in water columns. Another macrophyte, Potamogeton maackianus, one of dominant macrophytes in Lake Taihu, also showed high concentrations of MCs, indicating that they may play a vital role in elimination of MCs in Lake Taihu.

Results of both shrimps species showed that living in an environment with higher levels of MCs (the MC levels in water and algal cells were higher than in other samples) could lead to higher MC levels accumulated in the bodies of shrimp; a similar result was found in the James River Estuary for fish and shellfish [34]. The results suggested that levels of MC in tissues of shrimp, shellfish and some fish species could be associated with dietary exposure for consumers. The results for the three fish species (Neosalanx tangkahkeii taihuensis, Coilia ectenes and silver carp) caught in both 2013 and 2014 showed that fish living in an environment with higher MC concentrations had more MCs in their muscle, which was similar to the results for shrimp. The dominant species Hyporhamphus intermedius and Coilia ectenes, which are both pelagic species, accumulated higher MC levels in their body than other fish species. This may be because they live in the upper layer of the water body and thus have more access to algal cells. Meanwhile, they do not have a detox ability similar to that of silver carp. Therefore, they may pose potential risks to higher trophic animals and human beings [49,50].

Both laboratory and field studies indicate that the presence of MCs in aquatic ecosystemshad adverse impacts on aquatic plants [42,51-54]. Exposure to MCs could decrease the growth rate of Lemna gibba [51], Lemna minor and Wolffia arrhiza [54]. Increase of MCs in the water can cause oxidative stress and had adverse impacts on metabolism of aquatic plants by suppressing the soluble protein contents [53]. MCs had sublethal effects on aquatic fauna, including zooplankton [55,56], macroinvertebrates and aquatic insects [57-60]. Malbrouck and Kestemont reviewed the effect of MCs on fish and discussed the potential consequences in aquatic ecosystems [61]. In early life stages of fish, exposure to MCs had adverse effects on embryonic hatching, decreased survival and growth rate, and resulted in histopathological effects. In adults and juveniles, MC exposure could affect growth rate and had histopathological effects on several organs of fish [61-63]. Besides, the carnivorous fish are more sensitive to MCs than phytoplanktivorous fish [24,63]. Christoffersen reviewed the values of microcystin concentrations that have proved lethal or caused significant changes in physiological or behavioural processes [64]. Fish are the most tolerant $\left(0.5-20 \mu \mathrm{g}\right.$ toxin $\left.\cdot \mathrm{mL}^{-1}\right)$, phytoplankton are intermediately tolerant $\left(0.05-1 \mu \mathrm{g}\right.$ toxin $\mathrm{mL}^{-1}$ ), and macrophytes (Lemna and Elodea) and nano-sized protozoa (heterotrophic nanoflagellates) are the least tolerant organisms $\left(0.001-0.05 \mu \mathrm{g}\right.$ toxin $\left.\cdot \mathrm{mL}^{-1}\right)$. According to the MC levels in this study, MCs could cause significant effects on physiological or behavioural processes, or even death to some macrophytes and nano-sized protozoa in Lake Taihu. Other studies in Lake Taihu also showed that the Microcystis blooms strongly inhibited the population growth of the water flea, Daphnia magna, by reducing their survival rates, individual growth rate, or gross fecundity [65]. In the worst case, cyanobacterial blooms can eliminate filter-feeding zooplankton 
and change the competitive relations among zooplankton, which may undermine the food chain and destroy the ecological balance in aquatic ecosystems [65,66].

Although the MC concentration in the water of Lake Taihu was much lower than the WHO guideline value, the MC concentration in algal cells was several times of the guideline value which maybe released into water during drinking water treatment processes $[67,68]$ and pose risks to human health. From Table 3, the ADIs of MCs for one shrimp and three fish species exceeded the provisional TDI proposed by WHO, especially Hyporhamphus intermedius. Compared to previous studies sampled in blooming periods, the mean daily intakes of MCs were estimated to be 2.2 times the recommended TDI for MC-LR in Lake Taihu [69]. The MCs consumption risk of fish muscle in blooming periods was much higher than in non-blooming periods. However, some fish such as Coilia ectenes and Hyporhamphus intermedius collected from Lake Taihu during non-blooming periods could also pose risks to human beings. However, there are few studies considering the consumption risk of MC for children. Mulvenna et al. assessed the consumption risk of MCs taking adults and children separately [70]. The health guideline values in seafood for MC derived from the study were lower for children than for adults, indicating that safe seafood for adults is not necessarily safe for children.

\section{Conclusions}

Widespread MC contamination in water, algal cells, macrophytes, shrimps and fish was observed in Lake Taihu. MC accumulation followed the order of primary producer $>$ tertiary consumer $>$ secondary consumer $>$ primary consumer. The highest MCs in macrophytes, shrimp and fish tissue were found in Potamogeton maackianus, Exopalaemon modestus, and Hyporhamphus intermedius, respectively. MCs in their tissues can be associated with the dietary exposure of shrimp and three fish species: Neosalanx tangkahkeii taihuensis, Coilia ectenes and silver carp. Further studies are necessary to identify the relationship between dietary exposure and MC accumulation in tissue. Ceratophyllum demersum L. is an ideal plant to protect against Microcystis blooms and MCs in lakes due to its ability to absorb nutrients, accumulate large amounts of MCs and exhibittolerance to MCs, compared to other macrophytes. The ADIs of MCs for Exopalaemon modestus and three fish species, Coilia ectenes, Hyporhamphus intermedius and Carassius carassius, were all above the TDI proposed by WHO, which may pose threats to the health of local residents. Routine monitoring should be applied in Lake Taihu to avoid consumption of contaminated water, shrimps and fish.

\section{Materials and Methods}

\subsection{Study Area and Sampling Sites}

The most polluted part of Lake Taihu was selected as the study area according to Lake Taihu's eutrophication status [33]. Water and phytoplankton were both sampled at 12 sites (Figure 5). Macrophytes were sampled in the West coast (WC), South coast (SC), lake centre (LC) and Meiliang Bay (MLB) (Figure 5). Shrimps and fish were sampled in MLB (Figure 5).

\subsection{Sampling and Processing}

Water samples of Lake Taihu were taken on 24 September 2013 and 24 September 2014, when cyanobacterial blooms frequently appeared in the years before. Surface water samples of $2 \mathrm{~L}$ were collected at 12 sites using plastic bottles and were stored at $4{ }^{\circ} \mathrm{C}$ in the dark before laboratory analysis (Figure 5).

In the laboratory, one litre of the sample water was pre-filtered using glass fibre filters (GF/C, Whatman, GE Healthcare UK Limited, Little Chalfont, Bucks, UK) under vacuum within 1 day. The filtered water was extracted by solid phase extraction (SPE) according to the procedures from Dai et al. [71]. The glass fibre filters were used to detect MCs in the algal cells. The extraction of MCs in algal cells followed a previous method [72]. 
Floating and rooted macrophytes were collectedon 24 September 2013 and 24 September 2014. Six macrophytes were sampled: Ceratophyllum inflatum Jao, Ceratophyllum demersum L., Hydrillaverticillata, Lemna minor, Potamogeton maackianus and Eichhornia crassipes (Figure 5). At least 3 individuals per species were collected. Two species of shrimp, Exopalaemon modestus and Macrobrachium nipponense, were sampled with the help of local fisherman on 24 September 2013 and 24 September 2014. Seven fish species including Hyporhamphus intermedius (Asian pencil halfbeak), Neosalanx tangkahkeii taihuensis (icefish), cyprinus carpio (common carp), Coilia ectenes (lake anchovy), Ctenopharyngodon idella (grass carp), Carassius carassius (crucian carp) and Hypophthalmichthys molitrix (silver carp) were also sampled with help from local fisherman on 24 September 2013 and 24 September 2014 (Figure 5). The weight and length of each shrimp and fish was measured. Then fish was immediately dissected. At least 3individuals per species were prepared. The individuals were mixed and frozen at $-20^{\circ} \mathrm{C}$ for storage before MCs quantification. For the fish samples of Ctenopharyngodon idella (grass carp), cyprinus carpio (common carp), Carassius carassius (crucian carp), and Hypophthalmichthys molitrix (silver carp) muscle and visceral (the whole inside part of the fish) tissues were taken for analysis. For other species, the whole fish was taken.

Samples of tissues were lyophilized, crushed and homogenized. Approximately $0.4 \mathrm{~g}$ dry weight $(\mathrm{dw})$ portions were extracted three times with $10 \mathrm{~mL}$ water:butanol:methanol=1:4:15 while stirring for $24 \mathrm{~h}$. The extract procedures followed the method from Xie et al. [73].

\subsection{MCs Quantification}

Microcystins were quantified using the method of [74] with some modification [33]. Samples in $\mathrm{MeOH}$ were injected into an Agilent 6460 QQQ HPLC-MS/MS equipped with an Agilent Zorbax Eclipse Plus column $(\mathrm{C} 18,2.1 \mathrm{~mm} \times 50 \mathrm{~mm}, 1.8 \mu \mathrm{m})$. Separation was accomplished using two phases. Phase A was $\mathrm{MeOH}$ and phase B was water with $0.1 \%$ formic acid (FA). The flow rate of the mobile phase was $0.5 \mathrm{~mL} / \mathrm{min}$. The temperature of column oven was set at $40{ }^{\circ} \mathrm{C}$. For more detailed information please see [33]. Instrument control, data processing and data analysis were conducted using Agilent MassHunter software B.04.00 (Agilent Technologies, Inc., Santa Clara, CA, USA, 2011). The MC concentrations of the samples from Lake Taihu were quantified by comparing the peak areas of the test samples to those of MC-LR, MC-YR and MC-RR standards from AXXORA Europe, Switzerland.

\subsection{Statistical Analysis}

Data were processed using SPSS 17.0 (SPSS, Inc., Chicago, IL, USA, 2008). Analysis of variance (ANOVA) was applied to find whether significant variation of MCs exists in water, algal cells and their total MCs between WC, SC, LC and MLB. ANOVA was also applied to find whether significant variation of MCs exists in water, algal cells and the total MCs between different years. Pearson correlation analysis was used to examine whether there were significant relationships between $\mathrm{MC}$ in macrophytes and MC in water and algal cells. Data were transformed by $\log (X+1)$ when the ANOVA and correlation analysis were conducted. The criterion for significance was $p<0.05$ and $p<0.01$.

Acknowledgments: This research was supported by National Nature Science Foundation of China (No. 91547206) and Jiangsu Water Resources Protection Project (No. 2015005). The authors are grateful to Catherine Rice for proofreading the English of the manuscript.

Author Contributions: J.J., Q.C. conceived and designed the field survey and experiments; J.J. performed field survey and experiments, and wrote the paper; Q.C. and T.L.L. revised the paper.

Conflicts of Interest: The authors declare no conflict of interest. 


\section{References}

1. Falconer, I.R. Cyanobacterial Toxins of Drinking Water Supplies: Cylindrospermopsins and Microcystins; CRC Press: Boca Raton, FL, USA, 2005.

2. Stewart, I.; Webb, P.M.; Schluter, P.J.; Fleming, L.E.; Burns, J.W.; Gantar, M.; Backer, L.C.; Shaw, G.R. Epidemiology of recreational exposure to freshwater cyanobacteria-An international prospective cohort study. BMC Public Health 2006, 6. [CrossRef] [PubMed]

3. Chorus, I.; Bartram, J. Toxic Cyanobacteria in Water: A Guide to Their Public Health Consequences, Monitoring and Management; E \& FN Spon: London, UK, 1999.

4. Paerl, H.W.; Huisman, J. Blooms like it hot. Sci. N. Y. Wash. 2008, 320, 57. [CrossRef] [PubMed]

5. Michalak, A.M.; Anderson, E.J.; Beletsky, D.; Boland, S.; Bosch, N.S.; Bridgeman, T.B.; Chaffin, J.D.; Cho, K.; Confesor, R.; Daloğlu, I. Record-setting algal bloom in lake erie caused by agricultural and meteorological trends consistent with expected future conditions. Proc. Natl. Acad. Sci. USA 2013, 110, 6448-6452. [CrossRef] [PubMed]

6. McElhiney, J.; Lawton, L.A. Detection of the cyanobacterial hepatotoxins microcystins. Toxicol. Appl. Pharmacol. 2005, 203, 219-230. [CrossRef] [PubMed]

7. Welker, M.; von Döhren, H. Cyanobacterial peptides-Nature's own combinatorial biosynthesis. FEMS Microbiol. Rev. 2006, 30, 530-563. [CrossRef] [PubMed]

8. Wiegand, C.; Pflugmacher, S. Ecotoxicological effects of selected cyanobacterial secondary metabolites a short review. Toxicol. Appl. Pharmacol. 2005, 203, 201-218. [CrossRef] [PubMed]

9. Ferrão-Filho, A.D.S.; Kozlowsky-Suzuki, B. Cyanotoxins: Bioaccumulation and effects on aquatic animals. Mar. Drugs 2011, 9, 2729-2772. [CrossRef] [PubMed]

10. Skulberg, O.M. Giftvirkninger av Blågrønnalger-Første Tilfelle av Microcystis-Forgiftning Registrert $i$ Norge (Toxic Effects of Blue-Green Algae-First Case of Microcystis Poisoning Reported from Norway); Norsk Institutt for Vannforskning: Oslo, Norway, 1979; p. 42.

11. Eriksson, J.E.; Meriluoto, J.; Lindholm, T. Can cyanobacterial toxins accumulate in aquatic food chains? In Proceedings of the 4th International Symposium of Microbiol Ecology, Ljubljana, Yugoslavia, 24-26 August 1986; p. 658.

12. Bury, N.R.; Eddy, F.B.; Codd, G.A. The effects of the cyanobacterium microcystis aeruginosa, the cyanobacterial hepatotoxin microcystin-LR, and ammonia on growth rate and ionic regulation of brown trout. J. Fish Biol. 1995, 46, 1042-1054. [CrossRef]

13. Matsunaga, H.; Harada, K.I.; Senma, M.; Ito, Y.; Yasuda, N.; Ushida, S.; Kimura, Y. Possible cause of unnatural mass death of wild birds in a pond in Nishinomiya, Japan: Sudden appearance of toxic cyanobacteria. Nat. Toxins 1999, 7, 81-84. [CrossRef]

14. Paskerová, H.; Hilscherová, K.; Bláha, L. Oxidative stress and detoxification biomarker responses in aquatic freshwater vertebrates exposed to microcystins and cyanobacterial biomass. Environ. Sci. Pollut. Res. 2012, 19, 2024-2037.

15. Gugger, M.; Lenoir, S.; Berger, C.; Ledreux, A.; Druart, J.C.; Humbert, J.F.; Guette, C.; Bernard, C. First report in a river in france of the benthic cyanobacterium phormidium favosum producing anatoxin-A associated with dog neurotoxicosis. Toxicon 2005, 45, 919-928. [CrossRef] [PubMed]

16. Nasri, H.; El Herry, S.; Bouaïcha, N. First reported case of turtle deaths during a toxic microcystis spp. Bloom in Lake Oubeira, Algeria. Ecotoxicol. Environ. Saf. 2008, 71, 535-544. [CrossRef] [PubMed]

17. Pouria, S.; De, A.A.; Barbosa, J.; Cavalcanti, R.L.; Barreto, V.T.S.; Ward, C.J.; Preiser, W.; Poon, G.K.; Neild, G.H.; Codd, G.A. Fatal microcystin intoxication in haemodialysis unit in Caruaru, Brazil. Lancet 1998, 352, 21-26. [CrossRef]

18. Billam, M.; Mukhi, S.; Tang, L.; Gao, W.; Wang, J.S. Toxic response indicators of microcystin-LR in $\mathrm{f} 344$ rats following a single-dose treatment. Toxicon 2008, 51, 1068-1080. [CrossRef] [PubMed]

19. Li, Y.; Chen, J.A.; Zhao, Q.; Pu, C.W.; Qiu, Z.Q.; Zhang, R.P.; Shu, W.Q. A cross-sectional investigation of chronic exposure to microcystin in relationship to childhood liver damage in the three gorges reservoir region, China. Environ. Health Perspect. 2011, 119, 1483-1488. [CrossRef] [PubMed]

20. Ufelmann, H.; Kruger, T.; Luckas, B.; Schrenk, D. Human and rat hepatocyte toxicity and protein phosphatase 1 and 2A inhibitory activity of naturally occurring desmethyl-microcystins and nodularins. Toxicology 2012, 293, 59-67. [CrossRef] [PubMed] 
21. Yu, S.Z. Primary prevention of hepatocellular carcinoma. J. Gastroenterol. Hepatol. 1995, 10, 674-682. [CrossRef] [PubMed]

22. Yu, S.Z. Drinking water and primary liver cancer. In Primary Liver Cancer; Tang, Z.Y., Wu, M.C., Xia, S.S., Eds.; China Academic Publishers: New York, NY, USA, 1989; pp. 30-37.

23. Chen, J.; Xie, P.; Li, L.; Xu, J. First identification of the hepatotoxic microcystins in the serum of a chronically exposed human population together with indication of hepatocellular damage. Toxicol. Sci. 2009, 108, 81-89. [CrossRef] [PubMed]

24. Zhang, D.W.; Xie, P.; Liu, Y.Q.; Qiu, T. Transfer, distribution and bioaccumulation of microcystins in the aquatic food web in Lake Taihu, China, with potential risks to human health. Sci. Total Environ. 2009, 407, 2191-2199. [CrossRef] [PubMed]

25. Song, L.R.; Chen, W.; Peng, L.; Wan, N.; Gan, N.Q.; Zhang, X.M. Distribution and bioaccumulation of microcystins in water columns: A systematic investigation into the environmental fate and the risks associated with microcystins in meiliang bay, Lake Taihu. Water Res. 2007, 41, 2853-2864. [CrossRef] [PubMed]

26. Chen, J.; Xie, P. Microcystin accumulation in freshwater bivalves from Lake Taihu, China, and the potential risk to human consumption. Environ. Toxicol. Chem. 2007, 26, 1066-1073. [CrossRef] [PubMed]

27. Yang, M.; Yu, J.W.; Li, Z.L.; Guo, Z.H.; Burch, M.; Lin, T.F. Taihu Lake not to blame for Wuxi's woes. Science 2008, 319, 158. [CrossRef] [PubMed]

28. Peng, L.A.; Liu, Y.M.; Chen, W.; Liu, L.M.; Kent, M.; Song, L.R. Health risks associated with consumption of microcystin-contaminated fish and shellfish in three chinese lakes: Significance for freshwater aquacultures. Ecotoxicol. Environ. Saf. 2010, 73, 1804-1811. [CrossRef] [PubMed]

29. Chen, J.; Xie, P. Tissue distributions and seasonal dynamics of the hepatotoxic microcystins-LR and -RR in two freshwater shrimps, palaemon modestus and macrobrachium nipponensis, from a large shallow, eutrophic lake of the subtropical China. Toxicon 2005, 45, 615-625. [CrossRef] [PubMed]

30. Chen, J.; Xie, P. Seasonal dynamics of the hepatotoxic microcystins in various organs of four freshwater bivalves from the large eutrophic Lake Taihu of subtropical China and the risk to human consumption. Environ. Toxicol. 2005, 20, 572-584. [CrossRef] [PubMed]

31. Zhang, D.; Xie, P.; Liu, Y.; Chen, J.; Liang, G. Bioaccumulation of the hepatotoxic microcystins in various organs of a freshwater snail from a subtropical Chinese lake, Taihu Lake, with dense toxic microcystis blooms. Environ. Toxicol. Chem. 2007, 26, 171-176. [CrossRef] [PubMed]

32. Chen, J.; Zhang, D.W.; Xie, P.; Wang, Q.; Ma, Z.M. Simultaneous determination of microcystin contaminations in various vertebrates (fish, turtle, duck and water bird) from a large eutrophic chinese lake, Lake Taihu, with toxic microcystis blooms. Sci. Total Environ. 2009, 407, 3317-3322. [CrossRef] [PubMed]

33. Jia, J.; Luo, W.; Lu, Y.; Giesy, J.P. Bioaccumulation of microcystins (MCs) in four fish species from Lake Taihu, China: Assessment of risks to humans. Sci. Total Environ. 2014, 487, 224-232. [CrossRef] [PubMed]

34. Wood, J.D.; Franklin, R.B.; Garman, G.; McIninch, S.; Porter, A.J.; Bukaveckas, P.A. Exposure to the cyanotoxin microcystin arising from interspecific differences in feeding habits among fish and shellfish in the james river estuary, virginia. Environ. Sci. Technol. 2014, 48, 5194-5202. [CrossRef] [PubMed]

35. Lehman, P.W.; Teh, S.J.; Boyer, G.L.; Nobriga, M.L.; Bass, E.; Hogle, C. Initial impacts of microcystis aeruginosa blooms on the aquatic food web in the san francisco estuary. Hydrobiologia 2009, 637, 229-248. [CrossRef]

36. Zhu, M.; Paerl, H.W.; Zhu, G.; Wu, T.; Li, W.; Shi, K.; Zhao, L.; Zhang, Y.; Qin, B.; Caruso, A.M. The role of tropical cyclones in stimulating cyanobacterial (microcystis spp.) blooms in hypertrophic Lake Taihu, China. Harmful Algae 2014, 39, 310-321. [CrossRef]

37. WHO. Report of the Working Group on Chemical Substances in Drinking Water; WHO: Geneva, Switzerland, 1997.

38. Gupta, N.; Pant, S.C.; Vijayaraghavan, R.; Rao, P.V.L. Comparative toxicity evaluation of cyanobacterial cyclic peptide toxin microcystin variants (LR, RR, YR) in mice. Toxicology 2003, 188, 285-296. [CrossRef]

39. Sotton, B.; Guillard, J.; Anneville, O.; Maréchal, M.; Savichtcheva, O.; Domaizon, I. Trophic transfer of microcystins through the lake pelagic food web: Evidence for the role of zooplankton as a vector in fish contamination. Sci. Total Environ. 2014, 466-467, 152-163. [CrossRef] [PubMed]

40. Li, L.; Xie, P.; Chen, J. Biochemical and ultrastructural changes of the liver and kidney of the phytoplanktivorous silver carp feeding naturally on toxic microcystis blooms in Taihu Lake, China. Toxicon 2007, 49, 1042-1053. [CrossRef] [PubMed] 
41. Filizadeh, Y.; Ahmadi, H.; Zolfinejad, K. The feeding preferences of grass carp (Ctenopharyngodon idella val.) for ten aquatic plants. In Proceedings of The Fourth International Iran \& Russia Conference, ShahreKord, Iran, 8-10 September 2004; pp. 1447-1451.

42. Romero-Oliva, C.S.; Contardo-Jara, V.; Block, T.; Pflugmacher, S. Accumulation of microcystin congeners in different aquatic plants and crops-A case study from Lake Amatitlan, Guatemala. Ecotoxicol. Environ. Saf. 2014, 102, 121-128. [CrossRef] [PubMed]

43. Yin, L.; Huang, J.; Li, D.; Liu, Y. Microcystin-rr uptake and its effects on the growth of submerged macrophyte Vallisneria natans (lour.) hara. Environ. Toxicol. 2005, 20, 308-313. [CrossRef] [PubMed]

44. Romero-Oliva, C.S.; Contardo-Jara, V.; Pflugmacher, S. Time dependent uptake, bioaccumulation and biotransformation of cell free crude extract microcystins from lake amatitlan, guatemala by ceratophyllum demersum, egeria densa and hydrilla verticillata. Toxicon 2015, 105, 62-73. [CrossRef] [PubMed]

45. Cedergreen, N.; Madsen, T.V. Nitrogen uptake by the floating macrophyte lemna minor. New Phytol. 2002, 155, 285-292. [CrossRef]

46. Lombardo, P.; Cooke, G.D. Ceratophyllum demersum-phosphorus interactions in nutrient enriched aquaria. Hydrobiologia 2003, 497, 79-90. [CrossRef]

47. Pflugmacher, S.; Wiegand, C.; Beattie, K.A.; Krause, E.; Steinberg, C.E.W.; Codd, G.A. Uptake, effects, and metabolism of cyanobacterial toxins in the emergent reed plant Phragmites australis (Cav.) trin. Ex steud. Environm. Toxicol. Chem. 2001, 20, 846-852. [CrossRef]

48. Romero-Oliva, C.S.; Contardo-Jara, V.; Pflugmacher, S. Antioxidative response of the three macrophytes ceratophyllum demersum, egeria densa, and hydrilla verticillata to a time dependent exposure of cell-free crude extracts containing three microcystins from cyanobacterial blooms of Lake Amatitlan, Guatemala. Aquat. Toxicol. 2015, 163, 130-139. [CrossRef] [PubMed]

49. De Figueiredo, D.R.; Azeiteiro, U.M.; Esteves, S.M.; Gonçalves, F.J.M.; Pereira, M.J. Microcystin-producing blooms-A serious global public health issue. Ecotoxicol. Environ. Saf. 2004, 59, 151-163. [CrossRef] [PubMed]

50. Codd, G.A.; Morrison, L.F.; Metcalf, J.S. Cyanobacterial toxins: Risk management for health protection. Toxicol. Appl. Pharmacol. 2005, 203, 264-272. [CrossRef] [PubMed]

51. Saqrane, S.; Ghazali, I.E.; Ouahid, Y.; Hassni, M.E.; Hadrami, I.E.; Bouarab, L.; del Campo, F.F.; Oudra, B.; Vasconcelos, V. Phytotoxic effects of cyanobacteria extract on the aquatic plant lemna gibba: Microcystin accumulation, detoxication and oxidative stress induction. Aquat. Toxicol. 2007, 83, 284-294. [CrossRef] [PubMed]

52. Freitas, M.; Azevedo, J.; Pinto, E.; Neves, J.; Campos, A.; Vasconcelos, V. Effects of microcystin-LR, cylindrospermopsin and a microcystin-LR/cylindrospermopsin mixture on growth, oxidative stress and mineral content in lettuce plants (Lactuca sativa L.). Ecotoxicol. Environ. Saf. 2015, 116, 59-67. [CrossRef] [PubMed]

53. Zhang, M.; Wang, Z.Q.; Xu, J.; Liu, Y.Q.; Ni, L.Y.; Cao, T.; Xie, P. Ammonium, microcystins, and hypoxia of blooms in eutrophic water cause oxidative stress and $\mathrm{C}-\mathrm{N}$ imbalance in submersed and floating-leaved aquatic plants in Lake Taihu, China. Chemosphere 2011, 82, 329-339. [CrossRef] [PubMed]

54. Mitrovic, S.M.; Allis, O.; Furey, A.; James, K.J. Bioaccumulation and harmful effects of microcystin-LR in the aquatic plants lemna minor and wolffia arrhiza and the filamentous alga chladophora fracta. Ecotoxicol. Environ. Saf. 2005, 61, 345-352. [CrossRef] [PubMed]

55. Ferr ao-Filho, A.S.; Domingos, P.; Azevedo, S.M.F.O. Influences of a Microcystis aeruginosakützing bloom on zooplankton populations in Jacarepagu'a Lagoon (Rio de Janeiro, Brazil). Limnol. Ecol. Manag. Inland Waters 2002, 32, 295-308. [CrossRef]

56. Da Silva Ferr ao-Filho, A.; Azevedo, S.M.F.O. Effects of unicellular and colonial forms of toxic microcystis aeruginosa from laboratory cultures and natural populations on tropical cladocerans. Aquat. Ecol. 2003, 37, 23-35. [CrossRef]

57. Beattie, K.A.; Ressler, J.; Wiegand, C.; Krause, E.; Codd, G.A.; Steinberg, C.E.W.; Pflugmacher, S. Comparative effects and metabolism of two microcystins and nodularin in the brine shrimp artemia salina. Aquat. Toxicol. 2003, 62, 219-226. [CrossRef]

58. Delaney, J.M.; Wilkins, R.M. Toxicity of microcystin-LR, isolated from microcystis aeruginosa, against various insect species. Toxicon 1995, 33, 771-778. [CrossRef] 
59. Hiripi, L.; Nagy, L.; Kalmar, T.; Kovacs, A.; Vörös, L. Insect (Locusta migratoria migratorioides) test monitoring the toxicity of cyanobacteria. Neurotoxicology 1997, 19, 605-608.

60. White, S.H.; Duivenvoorden, L.; Fabbro, L.D. A decision-making framework for ecological impacts associated with the accumulation of cyanotoxins (cylindrospermopsin and microcystin). Management 2005, 10, $25-37$. [CrossRef]

61. Malbrouck, C.; Kestemont, P. Effects of microcystins on fish. Environ. Toxicol. Chem. 2006, 25, 72-86. [CrossRef] [PubMed]

62. Zimba, P.; Khoo, L.; Gaunt, P.; Brittain, S.; Carmichael, W. Confirmation of catfish, ictalurus punctatus (rafinesque), mortality from microcystis toxins. J. Fish Dis. 2001, 24, 41-47. [CrossRef]

63. Qiu, T.; Xie, P.; Ke, Z.; Li, L.; Guo, L. In situ studies on physiological and biochemical responses of four fishes with different trophic levels to toxic cyanobacterial blooms in a large chinese lake. Toxicon 2007, 50, 365-376. [CrossRef] [PubMed]

64. Christoffersen, K. Ecological implications of cyanobacterial toxins in aquatic food webs. Phycologia 1996, 35, 42-50. [CrossRef]

65. Liu, L.P.; Li, K.; Chen, T.Y.; Dai, X.L.; Jiang, M.; Diana, J.S. Effects of microcystis aeruginosa on life history of water flea daphnia magna. Chin. J. Oceanol. Limnol. 2011, 29, 892-897. [CrossRef]

66. Sun, X.; Tao, M.; Qin, B.; Qi, M.; Niu, Y.; Zhang, J.; Ma, Z.; Xie, P. Large-scale field evidence on the enhancement of small-sized cladocerans by microcystis blooms in Lake Taihu, China. J. Plankton Res. 2012, 34, 853-863. [CrossRef]

67. Daly, R.I.; Ho, L.; Brookes, J.D. Effect of chlorination on microcystis aeruginosa cell integrity and subsequent microcystin release and degradation. Environ. Sci. Technol. 2007, 41, 4447-4453. [CrossRef] [PubMed]

68. Jones, G.J.; Orr, P.T. Release and degradation of microcystin following algicide treatment of a microcystis aeruginosa bloom in a recreational lake, as determined by HPLC and protein phosphatase inhibition assay. Water Res. 1994, 28, 871-876. [CrossRef]

69. Chen, J.; Xie, P.; Zhang, D.W.; Ke, Z.X.; Yang, H. In situ studies on the bioaccumulation of microcystins in the phytoplanktivorous silver carp (Hypophthalmichthys molitrix) stocked in Lake Taihu with dense toxic microcystis blooms. Aquaculture 2006, 261, 1026-1038. [CrossRef]

70. Mulvenna, V.; Dale, K.; Priestly, B.; Mueller, U.; Humpage, A.; Shaw, G.; Allinson, G.; Falconer, I. Health risk assessment for cyanobacterial toxins in seafood. Int. J. Environ. Res. Public Health 2012, 9, 807-820. [CrossRef] [PubMed]

71. Dai, R.; Liu, H.; Qu, J.; Ru, J.; Hou, Y. Cyanobacteria and their toxins in guanting reservoir of Beijing, China. J. Hazard. Mater. 2008, 153, 470-477. [CrossRef] [PubMed]

72. Su, C.; Dai, R.; Liu, H.; Zhao, X.; Qu, J. Effects of different phosphorus sources and its concentrations on the growth and toxin production of microcystis aeruginosa. Acta Sci. Circumst. 2013, 33, 2546-2551.

73. Xie, L.Q.; Xie, P.; Ozawa, K.; Honma, T.; Yokoyama, A.; Park, H.D. Dynamics of microcystins-LR and -RRin the phytoplanktivorous silver carp in a sub-chronic toxicity experiment. Environ. Pollut. 2004, 127, 431-439. [CrossRef] [PubMed]

74. Li, J.Z. Agilent 1260 Uhplc/6460qqq used for the detection of microcystins. Environ. Chem. 2011, 30, 731-733.

(C) 2016 by the authors; licensee MDPI, Basel, Switzerland. This article is an open access article distributed under the terms and conditions of the Creative Commons Attribution (CC-BY) license (http:/ / creativecommons.org/licenses/by/4.0/). 